\title{
European Banking Union - an institutional analysis
}

\author{
Barbara MAJEWSKA-JURCZYK \\ WSB University in Wroclaw, Poland
}

Received: 05.11.2020, Revised: 17.12.2020, Revised: 02.03.2021, Revised: 23.03.2021, Accepted: 23.03.2021

doi: http://dx.doi.org/10.29015/cerem.896

\begin{abstract}
:
Aim: The Banking Union is an important step towards a genuine Economic and Monetary Union. The strengthening of the European banking system has become topic of debate since the 2008 crisis, when it became clear that stability and security of the system security may require increased supervision over operations conducted. The Banking Union was created to avoid the situation that taxpayers are first in line pay for bailing out ailing banks. The Banking Union consists of three pillars: 1) the Single Supervisory Mechanism (SSM), which centralizes supervision of European banks around the European Central Bank, 2) the Single Resolution Mechanism (SRM), which main purpose is to ensure the efficient resolution for recapitalization failing banks, and 3) the European Deposit Insurance Scheme (EDIS), which is still unfinished. The creation of the Banking Union is accompanied by remarkable transfer of sovereignty to the European level. This article aims to provide an overview of the changes unfolding across the Banking Union from a law and economics perspective, and to explain the role of the European Central Bank in supervision over the banking system, which is different from the policy of controlling prices through determining the level of interest rates and keeping inflation under control.
\end{abstract}

Design/Research methods: The analysis of the functioning Banking Union is based on review of literature and analysis of reports and legal acts.

Findings: The Banking Union supports financial integration in the EU by implementing a common set of rules and a common supervisory and resolution mechanism. The creation of the Deposit Insurance Scheme is likely to contribute to the protection of banks and consumers in case of a potential future crisis. The author argues that the European Central Bank as a supervisor of the financial market should create a second supervisory body, which would significantly strengthen the system and allow the ECB more efficiently fulfil its task as chief supervisor.

Keywords: European Union, Banking Union, European Central Bank, Single Supervisory Mechanism, Single Resolution Mechanism, Deposit Insurance Scheme.

JEL: K10, K20

Correspondence address: Barbara MAJEWSKA-JURCZYK,, WSB University in Wrocław, ul. Fabryczna 29-31, 53-609 Wrocław, Poland. E-mail: barbara.majewska-jurczyk@wsb.wroclaw.pl. 


\section{Introduction}

The Banking Union complements the Economic and Monetary Union and the internal market of the European Union (EU). It unifies the responsibility for supervision, recovery and resolution of banks. Moreover, it obligates banks operating across the euro area to comply with the rules applicable in the European Union stipulating that banks which commit errors are required to deal with them. In the wake of the 2008-2010 crisis it became clear, that what had to be established, especially in the euro area, was a new system of financial security, that would increase supervision over operations conducted by banks. Węcławski (2015) notes that change within the EU financial security system aim at the emergence of new institutions and new supervision standards. According to Węcławski, these changes should not only lead to micro-prudential but also macro-prudential supervision, the requirement of better endowment of banks with equity capital, increased crossborder supervision, the transfer of responsibility for the stability of large banks from public authorities onto banks' owners and debtors as well as on the banking sector.

The setting-up of the European Banking Union constitutes one of the most important legal and institutional changes in the institutional system of the European Union. The European Commission presented its own legislative initiative providing the basis for this in June 2012, when the European Council issued a decision authorizing the setting-up of a Banking Union within the euro area. The aim was to implement a more efficient banking supervision within the EU by authorizing the European Central Bank to supervise the euro area, including the euro-area Member States. The proposition of the Commission was comprised of three pillars: a Single Supervisory Mechanism (SSM) for banking supervision, a Single Resolution Mechanism (SRM) for the recovery of the banking system and European Deposit Insurance Scheme (EDIS). Establishing these three pillars was recognized as absolutely necessary for financial stability in the euro area .

Common supervision, crisis management and deposit insurance, in the opinion of the European Commission, will allow for deeper financial integration. This will reinforce financial stability in the Member States participating in the Banking Union and in the European Union as the whole. A more stable banking sector will mean 
greater financing opportunities for companies of all sizes and more jobs and growth for European citizens. Deeper financial integration is also key to provide a wider choice of services at lower prices (COM 2017). This article aims to provide an overview of the changes unfolding across the Banking Union from a law and economics perspective, and to explain the role of the European Central Bank in supervision over the banking system, which is different from the policy of controlling prices through determining the level of interest rates and keeping inflation under control.

\section{Legal and institutional context of Banking Union}

The origins of the Banking Union dates back to June 2012 (Council 2012), when the European bond market was experiencing strong turbulences brought about by the crisis in the Spanish banking system, whose potential failure could have had incalculable consequences for the entire euro area. At that time, Spain conducted negotiations with representatives of the European Commission on terms and conditions of granting aid to the Spanish banking system. It was also at that time, that Herman van Rompuy, President of the European Council (Van Rompuy 2012) presented his own proposal aimed at putting an end to the antinomy existing between the banking crisis and the state of indebtedness of the sovereign euro-area Member States. In its essence, van Rompuy's proposal was to create a European Banking Union, which would be based on the following three pillars: firstly, strengthening the European Central Bank in terms of efficient supervision of all the euro-area banks, secondly, creating a bank deposit guarantee scheme for countries incapable of managing the capacity of their own banking system, and thirdly, setting up a mechanism and fund dealing with the resolution of banks which need that, without burdening the euro-area taxpayers with thus-related costs.

The publication of the President of the European Council constituted the basis underlying the decision of the European Council of June 2012 on setting up a Banking Union within the euro area. The subsequent step in the reform of the euro area involved preparing a project by the European Commission (COM 2012) in the 
form of the Regulation of the Council of September 2012, which granted the European Central Bank a supervisory role across the euro area. The competences of the European Central Bank within the euro area were to be performed within the framework of the operation of the Single Supervisory Mechanism, consisting of an executive body - Supervisory Board (SB), whose main task would involve in the first place the responsibility for licensing, monitoring and implementing relevant regulations on liquidity, capital and other important issues. Moreover, what was also to contribute to the stability of the banking sector in the EU were the following measures: Single Resolution Mechanism and European Deposit Guarantee Scheme. The European Central Bank would also have the competence to approve rescue plans. The plan devised by van Rompuy also assumed, that a special procedure would be created involving the protection of deposits, which represents the third pillar of the Banking Union (Alexander 2012). On June 10, 2013 the European Commission proposed the adoption of the relevant regulations on the aforementioned issue. The draft directive was adopted by the Council and passed by the European Parliament in 2014.

\section{Banking Union and internal market}

The integration of bank regulations has long been sought as a mean to strengthen the banking system as a condition for the functioning of the common market. This idea dates back to 1957 and the Treaty of Rome in which for the first time the relevant regulations were put in place laying the foundation for the future economic and financial integration of Europe. Initially, it was predominantly about being able to settle freely and allowing for a free flow of people, services and capital across participating members. With respect to the harmonization of financial regulations, the Single European Act of 1986 represented a big step forward, allowing the so called Second Banking Directive to be implemented, with the directive facilitating considerably the operation of European banks across other Member States of the Union, without the requirement of having to obtain additional permits from the country where a particular bank planned to launch its operations. 
This policy was supported by the Union institutions as well as by individual governments of the Member States following the assumption, that an increase in competition and intensification of the banking activity within the framework of a single market would be to the advantage of both banks and consumers. The 2008 banking crisis revealed, that the lack of appropriate unified regulations as regards the supervision of the operations of the banking systems of different EU Member States ultimately triggered an uncontrollable sovereign debt crisis, that threatened the cohesion of the euro area. In light of the above, in February 2009 the High Level Group chaired by Jacques de Larosière prepared a report, in which it proposed to launch a reform of the European financing sector with its main focus being the creation of three supervisory bodies aimed at safeguarding the functioning of the EU banking sector in the future (Ferran 2014). Drawing on the group report, the European Commission proposed setting up the European System of Financial Supervision, which would consist of authorities regulating the operations of the banking system, authorities responsible for security and operations of the monetary markets and authorities responsible for the European social security system. The chief objective of the above mentioned institutions would be to monitor and promote more effective regulation and supervision of the operations of the European financial markets, thereby contributing to the more efficient functioning of the common market.

That the tightening of the regulatory policy in the banking sector was the right move was confirmed by the debt crisis, that broke out in Greece in May 2010, when Greece had to accept an aid package put together by the European Commission and the International Monetary Fund. In May 2012 the debt crisis in the euro area deepened significantly when Spain was forced to use the aid package. At that time it was both the European Commission and representatives of the German government who recognized, that in order for further aid packages to be delivered, it was necessary to advance the institutional consolidation within the scope of the banking system supervision at the level of the EU institutions. The Commission believed, that in order to avoid the risk of excessive banks' debt across the euro area this step was necessary (Ferran 2014). The European Central Bank (ECB) was indicated as the most suitable EU institution endowed with the capacity to fulfil this 
responsibility given the ECB's high credibility and authority, its successes regarding anti-inflationary policy, as well as its independence from other centers of political power at the level of the EU and the Member States. Furthermore, the creation of the Banking Union supervised by an already existing institution was regarded as a measure meant to improve the functioning of the common market, in light of the future actions seeking to counter the segmentation of the banking system in some of the Member States (Grunewald 2014: 271-273).

The financial instability in larger Member States of the euro area from the middle of 2011 led to renewed thinking about the interdependence between banking policy, financial integration and financial stability. In April 2012, the IMF managing director $\mathrm{CH}$. Lagarde confirmed the earlier opinion, that the euro monetary union should to be supported by stronger financial integration in the form of unified supervision, a single bank resolution authority with a common backstop, and a single deposit insurance fund (IMF/CFP 2012). Suggestions for more integrated European banking supervision were further discussed during an informal European Council meeting in May 2012.

As mentioned above, the President of European Council, H. Van Rompuy, called for deeper integration in the Eurozone and proposed to create a Banking Union encompassing direct recapitalization of banks by the European Stability Mechanism, a common financial supervisor, a common bank resolution scheme and a deposit guarantee fund (Van Rompuy 2012).

The Regulation (EU) No 806/2014 of the European Parliament and the Council in point 1 says, that the financial and economic crisis has shown, that the functioning of the internal market for banking services is under threat. This is a real source of concern in the internal market, in which banks should be able to carry out significant cross-border activities (Regulation 806/2014).

Differences between national resolution rules in different Member States and corresponding administrative practices and the lack of unified decision-making process for resolution in the Banking Union contribute to lack of confidence and market instability. Different incentives and practices of Member States in the treatment of creditors of banks have an impact on the perceived credit risk, financial soundness and solvency of their banks and thus create an uneven playing field. 
Divergences between national resolution rules in different Member States and corresponding administrative practices may lead banks and customers to have higher borrowing costs because of their place of establishment and irrespective of their real creditworthiness. So, customers of banks in some Member States face higher borrowing rates than customers of banks in other Member States, irrespective of their own creditworthiness. This undermines public confidence in the banking sector and obstructs the exercised of the freedom of establishment and the free provision of services within the internal market because financing costs would be lower without such differences in practices of Member States (Regulation 806/2014).

\section{Single Supervisory Mechanism}

In June 2012, more than two decades after the entry into force of the Maastricht Treaty, Eurogroup (2012) proposed to activate Article 127(6) of the Treaty on the Functioning of the European Union (TFEU) as a legal instrument allowing for setting-up a Single Supervisory Mechanism (SSM) for the purpose of governing and supervising the banks across the euro area, putting finally an end to the dichotomy in terms of the monetary policy controlled by the ECB and banking supervision under control of the EU Member States. Thus, the ECB was granted power to control about six thousand banks operating across the legal area of the European Union. Following a long debate and important amendments made by the Council and the European Parliament, the regulations regarding the SSM over the banking system were eventually passed in October 2013, to be entered into force the following month in November 2013. After a vacatio legis of one year they have been in force since November 2014 (Regulation 806/2014). According to point 7 of this Regulation, SSM should assure that the EU policy relating to the prudential supervision of credit institutions is implemented in a coherent manner, that the single rulebook for financial services is applied in the same manner to credit institutions in the euro area Member States and those non-euro area Member States, who choose to participate in the SSM and that those credit institutions are subject to supervision of the highest quality. 
It is worth mentioning that the Single Supervisory Mechanism constitutes the main pillar of the Banking Union, being comprised of the ECB, as well as the representatives of the Member States forming the euro area. The main goal of the newly created supervisory system is to ensure the security of the operations of the European banking system and to ensure the unity and integrity of the internal common market (Walker 2014). All the euro-area Member States are automatically members of the SSM while the non-euro Member States may decide whether to cooperate closely with the SSM as part of the operations of competent national authorities. With respect to working closely together with national authorities within the scope of the banking systems of those EU countries which are not in the euro area, the ECB was authorized to adopt a special memorandum, in which it is explained how it intends to cooperate with the central banks in the non-euro area Member States as part of the bank's supervisory role (Smits 1997).

The European Central Bank is responsible for supervising directly the largest banks, which represent over $85 \%$ of the banking assets in the euro-area, as well as being partially responsible for the supervision of smaller European banks, with the supervision being conducted by the relevant authorities of the Member States (European Banking Federation 2019: 26).

\section{Constitutional prerequisites for establishing the Banking Union}

With the debt crises emerging, it became apparent that what was acutely needed was the implementation of relevant regulations seeking to prevent financial crises from occurring in the future. Owing to its reputation, independence and financial discipline, the ECB seemed to be the only institution which could be entrusted with this task. In 2012, when the Council issued the key decision allowing the Banking Union to be set up, it was not entirely clear what would be the legal bases underlying the functioning of this union and whether its administration should be carried out by an already existing institution or whether or not to establish a new one. The key question was concerned with the constitutional underpinnings of this decision. At that time only two options came into play: to set up a new institution or 
to rely on the ECB. The first option would imply changing the treaties, which would be a long and uncertain endeavour given the lack of political stability in some of the EU countries. The choice of the second option did not rule out changes in the treaties. Eventually no decision was made as to any treaty amendments, because of the time pressure and uncertain situation on the international markets. The plan was to use the already existing treaty provisions as the basis for the measures to be implemented. Consequently, what was considered to form the constitutional basis for establishing the Banking Union was Article 127(6) of the Treaty on the Functioning of the European Union, which stipulates that the Council, acting in accordance with a special legislative procedure, may unanimously and after consulting the European Parliament and the ECB, confer specific tasks on the European Central Bank concerning responsibilities relating to supervision of financial institutions. A more in-depth analysis of Article 127(6) together with Article 13(2) of the Treaty on the Functioning of the European Union, which stipulates that institutions act within limits and in conformity with the law, shows that there are substantial limitations of constitutional nature in terms of granting further competences to the ECB to govern the Banking Union. The authority of the ECB extends only to individual financial institutions and it is not over financial conglomerates or investment firms. The conclusion to be drawn from the analysis of Article 127(6) of the Treaty on the Functioning of the European Union is, that if the European Central Bank is to be further strengthened by being granted new powers relating to the supervision of the financial market, here understood in its broad sense, the EU treaties will have to be changed. At this point one could suggest redefining Article 127(6) (before amending the EU treaties) in such a way as to make it possible to increase, if necessary, the supervisory competences of the ECB, as the bank has already reached the limit of its competences in accordance with the existing regulations (Hertig 2012). 


\section{European Central Bank's independence and effective banking supervision}

In accordance with Article 130 of the Treaty on the Functioning European Union, the overriding task of the ECB is to ensure price stability while performing its statutory tasks. It should be acknowledged that the European Central Bank has been very successful in this area for all the years of its work, ensuring the stability of the euro area and value of the common currency (Gerdesmeijer 2009; ECB 2021). Such consistent policy coupled by the bank's complete independence, enshrined in primary EU law, from any political interference has had the effect, that bank has enjoyed great authority, being recognized as an independent and apolitical institution. Considering the above criteria, one has to recognize that these features make the bank also an important authority for exercising the supervisory role over financial institutions.

The problem is that in conferring additional tasks on the ECB, such as the supervision over the banking system, is something entirely different from the policy of controlling prices through determining the level of interest rates and keeping inflation under control. In this case one has to accept that the premise materialized in the Maastricht Treaty which has not changed until this day and which consists in ensuring the ECB's independence has had a positive impact on sustaining the stable value of the euro while being a necessary requirement to safeguard the bank's mission laid down in Article 130 of the Treaty on the Functioning of the European Union (Gortsos 2015).

Moreover, exercising the role of banking supervision implies the assumption that a greater number of aims will have to be achieved, of which not all are fully cohesive, such as financial stability, protection of investors and deposits, protection of consumers or anti-money laundering prevention. The supervision thus perceived exerts an impact on limiting or modifying property rights which belong to entities, both to natural and legal persons, e.g. shareholders or creditors. Conducting such policy involves the employment of a significantly greater number of legal instruments than is the case for the implementation of monetary policy. What is also more difficult is to determine clearly whether or not the goals set have been met. 
The relationship between independency and responsibility is yet another issue. Unlike in the case of the monetary policy, where a complete independence from current policies is an asset, the banking supervision prompts the need to ensure a greater accountability to third bodies - in this case the ECB's independence anchored in the treaty appears rather problematic, since the lack of an adequate mechanism allowing for enforcing responsibility for decisions made violates the rule of law, and particularly, the principle of legality, and as such, one of the fundamental principles - values on which the European Union is based. In the long term, both competences of the ECB may prove to be incompatible with the primary aim of the bank which is to sustain price stability, because in order to ensure stability and liquidity of the banking sector, the Central Bank may be forced to conduct low interest rate policy, which may ultimately lead to easing the conditions for granting loans and increase inflation pressure. It is for this reason that combining these two competences in the ECB's hands appears to be such a controversial undertaking, whose effective implementation is in doubt, as in its exercising effective banking supervision the ECB may be forced to conduct a more lenient monetary policy (Alexander 2012). Thus, in the long run effective supervision may be conducted at the cost of an increase in inflation. Therefore, from the economic point of view, major concern is the potential conflict between price and financial stability, between monetary policy and banking supervision. The role of the ECB, prior to the financial crisis reflected by the German approach to central banking, was to target monetary or price stability. But the Eurocrisis 2010-2011 show that the Eurozone lacked proper crisis supervision and resolution mechanisms, so the new role of the ECB was necessary. The new supervisory mandate of the ECB requires a new staff with the required competence to exercise its supervisory function. In the opinion of Boyer and Ponce (2012), a second supervisory body would significantly strengthen the system and would allow the ECB efficiently and successfully fulfil its task as chief supervisor.

However, finding any other institutional solutions based on the Treaty on the Functioning of the European Union seems little realistic at this moment. That is the reason why the regulations adopted in November 2014 seek to build this kind of institutional architecture within the framework of the ECB's operations, which 
prevents the internal conflict within the bank's operations in that separate authorities have been selected to be responsible for the monetary policy and for the supervisory policy.

In the Communication issued in January 2018, the European Commission noted, that the ECB fully accomplished the tasks conferred on it since 2014, when it had begun to fulfil its supervisory role, especially considering the short deadlines envisaged for the implementation of the tasks and highly differentiated supervisory practices across 19 Member States.

\section{Single procedure for solving potential future banking crises}

As the Economic and Monetary Union needs a fully functioning Banking Union in order to be able to continue the single monetary policy and support financial risk diversification in all the Member States, on June 10, 2013 the European Commission proposed to establish a Single Resolution Mechanism (SRM) for potential banking crises that may occur in the future. The SRM entered into force on August 2014 and should constitute one of the three pillar of the Banking Union. The aim of the new mechanism was to create a more unified and harmonized way to overcome problems related to failing banks, that would involve a minimum share of taxpayers' money and reduced risk to the Member States' economies. Within the internal market, the failure of banks in one Member State may affect the stability of the financial markets of the EU as a whole. Effective and uniform resolution rules and equal conditions of resolution financing across the Member States is in the best interests of the Member States in which banks operate, but also ensures a level competitive playing field and improving the functioning of the internal market. In the absence of the SRM bank crises in the Member States participating in the SSM would have a stronger negative impact also in the non-participating Member States. The procedure for activating the aforementioned mechanism in SRM is as follows: The ECB identifies a particular bank which operates in the Member State as a unit facing potential failure, a special authority obligated to activate the procedure comprised of representatives of the European Commission, the ECB and representatives of the 
authorities of the country where the bank is based recommend a solution to the problem, the European Commission responds to the decision included in the recommendation on possible further steps that need to be taken, the national authorities are obligated to implement the recovery plan endorsed by the European Commission (see, e.g., Howarth, Quaglia 2014).

Although the procedure outlined above seemed effective, certain doubts were raised by the European Commission being granted such broad discretionary powers, especially in light of the content of Article 114 of the Treaty on the Functioning of the European Union. This article imposes far reaching restrictions on the EU institutions and authorities with respect to exercising discretionary power which are permitted, but only in cases concerned with the achievement of an important objective necessary for the sound functioning of the internal market (Ferran 2014).

Despite the implementation of the reform program for the financial sector, including, by virtue of the Capital Requirement Directive IV (Directive 2013/36/EU) and the Directive on bank recovery and resolution (Directive 2014/59/EU), stronger prudential requirements for banks, the key goal of the Banking Union is, in the Commission's view, the reversal of the fragmentation of the financial markets (Communication 2015). The fragmentation is to entail the weakening of the ties between banks and their national governments, while the supervision and resolution of the leading banks should be carried out at the level of the Banking Union.

In conclusion, it should be noted, that the elements of the Banking Union which are of institutional and regulatory nature, such as the unification of prudential norms in one rule book has already been implemented. Furthermore, all banks in the EU are supervised in accordance with the same standards; however, the banks of the euro-area countries are supervised by the European Central Bank in line with the supervisory task conferred on it. Finally, in case of failure, banks can be subject to recovery and resolution at the central level and in accordance with the same standards within the framework of the SRM. The scope of the SRM is a reflection of the Single Supervisory Mechanism, which means that the central body - the Single Resolution Board, in cooperation with national resolution authorities, is to ensure that in the situations where banks in the Banking Union were likely to fail in the 
future, they would be governed effectively with minimal costs for taxpayers and to the economy.

In the opinion of the Commission stated in the Communication of 2017 (COM 2017) the completed elements of the Banking Union operate correctly and the implementation of the SSM was successful. This, however, does not yet mean that the full implementation of the Banking Union has been accomplished, for what is still lacking is the common protection mechanism for deposit guarantee, whose implementation will allow the stability of the EU banking system to be secured, and thus the stability of the internal market operations in terms of the banking services. As it was said, in the Commission Communication from 2017, The European Deposit Insurance Scheme (EDIS) would underpin stability in the banking sector by providing strong and uniform insurance coverage for all such depositors, independent of their geographical location in the Banking Union (COM 2017). Already in 2015 the Commission proposed the transfer from National Deposit Guarantee Schemes to the EDIS, which would contribute to managing more effectively the cases of failing banks. Besides, risk ought to be reduced further and risk management should be improved in banks through relaxing further the interconnectedness between banks and their countries of origin.

In the Communication from the Commission to the European Parliament, the European Council, the Council and the ECB (COM 2019), the Commission stated, that quarantining deposits on the European level would ensure, that all deposits are equally protected across the Banking Union and thereby strengthen the confidence of depositors and mitigate the risk of bank runs.

In December 2018, the Leaders of the EU called for the work on the Banking Union for starting political negotiations on the Deposit Insurance Scheme, the third and still missing pillar of the Banking Union (Carmassi et al. 2018).

Apart from the actions of the European Commission and European Council as regards the completion of the Banking Union, these authorities provided for a number of additional measures aimed at reducing the risk involved in nonperforming loans. These loans affect profitability and viability of banks, and as such limit the banks' capacity to grant loans and ultimately may hamper economic growth. 


\section{Banking Union in the context of the COVID-19 pandemic}

The COVID pandemic underlines the need to strengthen European Banking Union, especially the third pillar, the European Deposit Insurance Scheme (EDIS), which is unfinished yet. Completing the EDIS is important, because without the EDIS, depositors protection will not be equal in Member States. The differences in fiscal strength in Member States could result in differing levels of depositor confidence. Moreover, now misalignment persists between centralized bank supervision and resolution in the Banking Union on the one hand and national deposit insurance, on the other hand.

In opinion of representatives of European Central Bank, Jochnik and Adams (2020), the Banking Union has withstood the test brought about by COVID-19 very well, because this was the first time, that a single banking supervisor rolled out a relief package for banks across the euro area. ECB supervision has ensured, that the European banking system as a whole is better poised to withstand sever crises such as COVID-19.

\section{Concluding remarks}

The analysis of the progressive transformation in terms of setting up the Banking Union shows, that this transformation has led to limitation of the supervision of the largest banks by national authorities in favour of the centralization of the competences of the ECB, whose powers were substantially enhanced by assigning new roles in terms of the banking supervision across the euro area. New bodies were set up and integrated within the ECB, operating in accordance with a special mechanism, with their only goal being to fulfil supervisory functions. In light of the fact that the primary task of the ECB is to prevent inflationary pressures, the supervisory operations are carried out by staff and new authorities identified especially for this purpose. In this way, the legislator sought to prevent the internally conflicting situation in which ensuring the liquidity of banks might not necessary be compatible with the monetary policy. Considering the far reaching tightening of the 
treaty provisions, in particular Article 114 of the Treaty on the Functioning of the European Union, as well as the case law of the EU Court of Justice in this respect, it is currently not possible to set up a separate authority that would specialize solely in performing the super advisory roles across the banking system. This kind of change, although necessary from the constitutional point of view, will only be possible, given the responsibility deficit and the potential conflict of interests of the authorities supervising the banking system under the ECB, after the amendment of the Treaty on the Functioning of the European Union.

Concerning to European Deposit Insurance Scheme, it should be noted, that finishing the EDIS would underpin stability in the banking sector by providing strong insurance coverage for all depositors independent of their geographical location in the European Union.

\section{References}

Alexander K. (2012), European Banking Union. Implementation challenges. Inquiry on European Banking Union, "Journal of Corporate Law Studies", no. 9, pp. 61-93.

Boyer P., Ponce J. (2012), Regulatory capture and banking supervision reform, "Journal of Financial Stability", vol. 8 no. 3, pp. 206-217.

European Banking Federation (2019), Banking in Europe. Facts and figures, https://www.ebf.eu/wpcontent/uploads/2020/01/EBF-Facts-and-Figures-2019-Banking-in-Europe.pdf [12.12.2020].

Carmassi J., Dobkowitz S., Evrard J., Parisi L., Silva A., Wedow M. (2018), Completing the Banking Union with a European Deposit Insurance Scheme. Who is afraid of cross-subsidisation?, European Central Bank, Occasional Paper Series, https://www.ecb.europa.eu/pub/pdf/scpops/ecb.op208.en.pdf [12.12.2020].

European Central Bank (ECB) Strategy, https://www.ecb.europa.eu/mopo/strategy/html/index.en.html [12.01.2021].

Ferran E. (2014), European Banking Union and the EU Single Financial Market. More differentiated integration or disintegration?, University of Cambridge Faculty of Law Research Paper no. 29.

Gerdesmeijer D. (2009), Price stability: why is it important for you? ECB, https://www.ecb.europa.eu/pub/pdf/other/whypricestabilityen.pdf [12.01.2021].

Gortsos C. (2015), The crisis-based EU financial regulatory intervention. Are we on the top of prudential wave?, "ERA Forum Journal of Academy of European Law", vol. 16 no. 1, pp. 89-110, http://link.springer.com/article/10.1007/s12027-015-0375-2 [12.12.2020]. 


\section{EUROPEAN BANKING UNION - AN INSTITUTIONAL ANALYSIS}

Grunewald S. (2014), The resolution of cross-border banking crisis in the European Union, Kluwer Law International, Alphen aan den Rijn.

Hertig A. (2012), Central Bank Governance, "Swiss Review of Business and Financial Market Law", vol. 84 no. 6 , pp. $486-493$.

Howarth D., Quaglia L. (2014), The steep road to European Banking Union. Constructing the Single Resolution Mechanism, "Journal of Common Market Studies", vol. 52, pp. 125-140, https://onlinelibrary.wiley.com/doi/10.1111/jcms.12178 [12.01.2021].

Jochnik K., Adams T. (2020), COVID-19: recovery and regulatory response, The 7 Annual European Banking Union Colloquium, European Central Bank, https:/www.bankingsupervision.europa.eu [20.01.2021].

Smits R. (1997), The European Central Bank. Institutional aspects, Kluwer International, Alphen aan den Rijn.

Van Rompuy H. (2012), Towards a genuine economic and monetary union, EUCO 120/12, https://www.consilium.europa.eu/media/33785/131201.pdf [27.03.2021].

Walker G. (2014), European Banking Law. Policy and program construction, British Institute of International and Comparative Law, London.

Węcławski J. (2015), Unia bankowa jako element europejskiej sieci bezpieczeństwa finansowego, „Zeszyty Naukowe Uniwersytetu Marii Curie-Skłodowskiej”, vol. XLIX no. 2, pp. 233-246.

\section{Legal acts}

Commission's Communication of 24.11.2015 to the European Parliament, the Council, the ECB, the Economic and Social Committee and the Committee of the Regions, "Towards setting up a banking union", Strasbourg.

Commission's Communication of 11.10.2017 to the European Parliament, the Council, the ECB, the Economic and Social Committee and the Committee of the Regions, Brussels, COM (2017) 592.

Communication from the Commission to the European Parliament, The European Council, The Council and the European Central Bank (2019), Brussels, 12.06.2019, COM (2019) 279.

Directive 2013/36/EU of the European Parliament and of the Council of 26 June 2013 on access to the activity of credit institutions and the prudential supervision of credit institutions and investment firms, OJ L 176.

Directive 2014/59/EU of the European Parliament and the Council of 15 May 2014 establishing a framework for the recovery and resolution of credit institutions and investment firms, OJ, L 173, June 2014.

Eurogrupa, Postanowienia ze szczytu, 29.06.2012, http:/consilium.europa.eu.

Regulation (EU) 806/2014 of the European Parliament and of the Council of 15 July 2014. 